\title{
Comprehensive review of the security and defence sector of Ukraine as a constituent part of security and defence management
}

\author{
Petro Krykun ${ }^{1}$ A; Oleksandr Zatynaiko ${ }^{2}$ B; Victor Korendovych 3 B \\ A National Institute for Strategic Studies, Ukraine

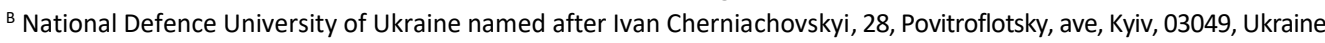

Received: June 5, 2021 | Revised: June 16, 2021 | Accepted: June 30, 2021

JEL Classification: H12, H56, H61.

DOI: $10.33445 /$ sds.2021.11.3.5

\begin{abstract}
In developing its national security system, Ukraine is transitioning from the non-functioning post-Soviet military organization of the state to a modern security and defence sector-operating under the European and Euro-Atlantic security principles. This transformation is facilitated by the implementation of a planning system in defence and security spheres based on the experience of NATO countries, and in particular the use of defence reviews, which have been conducted, and the comprehensive review of the security and defence sector. This article argues that the organization and methodological support of the reviews and realization of their results demand the implementation of more effective approaches in the achievement of the main purpose of the security and defence reform - the development of an effective system of national defence. The authors offer the basics of such approaches within the context of the national planning system of Ukraine.
\end{abstract}

Key words: national security, security and defence sector, comprehensive review of the security and defence sector, planning in security and defence.

\section{Introduction}

The main features of the modern military and political environment around Ukraine are connected with the temporary occupation by the Russian Federation of a part of Ukrainian territory - the Autonomous Republic of the Crimea and Sevastopol city - continual stirring by Russia of the armed conflict in the Eastern regions of Ukraine, building up of military forces near the Ukrainian border, conducting an aggressive policy towards Ukraine, and neglecting principles of international law and provisions of the intentional security treaties. In such conditions, Ukraine is improving the national security system to develop effective countermeasures to hybrid threats.
The concept of the security and defence sector (Law of Ukraine on National Security of Ukraine) (SDS) has become the basis for such a security system. It functionally unites the following: security forces, defence forces, the defence industrial complex, and citizens and civil organizations which voluntarily support national security. Indeed, the functional community of security, law enforcement, and defence structures, along with the implicit support of the Ukrainian society, European Union countries, NATO states, and international security organizations, as well as a concentration of available resources for countering actual and expected threats in the face of a much more powerful enemy, gave Ukraine an opportunity

\footnotetext{
${ }^{1}$ Senior consultant, e-mail: krykunpm@ukr.net, ORCID: 0000-0003-2780-559X

2 Leading Researcher, Ph.D (military sciences), e-mail: v.korendovich@nuou.org.ua

${ }_{3}^{3}$ Corresponding author: Prof., PhD (technical science), e-mail: v.korendovich@nuou.org.ua, ORCID: 0000-0003-2949-1870
} 
to stand up against the armed aggression of Russia in the eastern portion of the country. SDS's activity has sufficiently extended the state's abilities in achieving the goals of the national security and defence both by military and non-military means, namely political, diplomatic, economic, informational, etc. (Dieniezhkin M. M., Krykun P. M., 2008). The combination of military and non-military means of countering existing threats has become extremely important (Telelym V., Muzychenko D., Puda Yu.).

These and other factors prompted the necessity to revise the planning system in the spheres of the national security and defence, which would also need to adhere to the principles and approaches of NATO planning. The basics of such a system were at first provided in the Law On National Security of Ukraine (Law of Ukraine on National Security of Ukraine). The adjustment of such methods demanded a structural and functional rebuild of the planning system in the state authority bodies and state and military management. These measures boosted changes in the organization and methodology of the security and defence sector review as a systemic assessment of the status and the substantiation of perspectives on the development of the SDS. (Dieniezhkin M. M. Krykun P. M., Rusnak I. S., 2014).

The most topical issue became including the development of the planning documents in the security and defence spheres and the risk assessment to the joint process of conducting the Comprehensive Security and Defence Sector Review (CSDSR) (Law of Ukraine on National Security of Ukraine). At the moment of the introduction of the CSDSR, such requirements did not exist.

The article is devoted to the finding out the solution of issues regarding the basis of methodological maintenance of the joint systemic process of CSDSR measures, development of planning documents, including their modification.

\section{Results and discussion}

Having faced the unpredicted aggression of the Russian Federation, Ukraine took a range of urgent and very important decisions concerning the renaissance of all components of the SDS, and in particular a gradual abandonment of the conscript manning system and the development of a professional army, the formation of special operations forces, the restoration of the naval forces, the reconstruction of the territorial defence capability, the reformation of the military industrial complex, the re-equipment of the defence forces, and the implementation of the strategic course towards comprehensive defence with asymmetrical opportunities, among other measures. At the same time the issue of bringing these and other processes into a state management system encompassing the security and defence sector balanced in time, resources and priorities became acute. The integration of such complex processes relied on an updated planning system in the SDS.

Such a planning system shall meet the requirements of dynamic changes in the security environment, the creation of an effective SDS management system, as well as the balanced development of SDS's capabilities as a whole and its components. An effective use of resources provided by the state it is extremely important for this system. The CSDSR becomes the foundation for planning processes; it is considered an initial setting which brings to a single interrelated complex of measures, starting with the objective assessment of conditions and perspectives of capabilities development, the amount of necessary resource requirements for all SDS constituent parts, and to the realization of programs and plans.

The decision on conducting a CSDSR usually initiates the new cycle of planning in the sphere of the national security and defence within which the goals, main tasks, realization terms, responsible executors, etc., are defined. The CSDSR consolidates into a single process the range of revisions by corresponding spheres and 
general means concerning all the SDS's bodies. The President of Ukraine in his turn defines the order on the review of intelligence bodies of Ukraine and the review of the counter-terrorism system of the state. The methodological provision of these reviews is performed by the corresponding state bodies.

Relevant central state authorities define the order of other individual reviews included in the CSDSR, namely:

defence review - the Ministry of Defence of Ukraine;

review of public security and civil protection - the Ministry of Internal Affairs of Ukraine;

review of military-industrial complex - the central executive body which provides formation and implementation of state military and industrial policy;

review of the cyber protection of crucial informational infrastructure, state informational resources and information, protection of which is required by the law - the State Service of Special Communication and Protection of Information of Ukraine.

The National Institute for Strategic Studies undertakes the methodological support and oversight of the CSDSR as a joint systemic process, and this provides an opportunity to unite in a single harmonized process the measures of individual reviews, mentioned above, by aligning them into a logical sequence according to an agreed algorithm.

The Cabinet of Ministers of Ukraine provides financial support and organizes, controls, and preliminarily approves the results of the reviews. By doing that it creates conditions for approving financing of planned measures, as well as their concordance, systematic control of performance, and synergy of their results.

The main sense of the CSDSR is an assessment of the SDS as an integral functional system. The research conducted within the individual reviews are oriented to define the required key capabilities of the components of the SDS which should be quickly developed and adapted for the engagement as a part of joint capabilities according to the selected scenarios and situations. The scenarios provide the essential link between defence policy and capability objectives. The scenarios are common across the SDS and should accommodate the range of all operation types for the security and defence forces.

In the frame of CSDSR among others, the following issues are studied:

the combination of the capability and capacity of military formations and law enforcement agencies within the conditions when the enemy utilizes private military companies, illegal proxy forces, and protest actions in crisis-ridden regions;

the complex usage of military and nonmilitary forms and ways of actions (activities);

the use of joint capabilities to resolve domestic security issues, namely: the readiness of the SDS and society to oppose terrorism and anti-constitutional and illegal actions;

the functioning of the national security system and the stability of crisis-response infrastructure;

the reaction to hazards of natural and technogenic nature, epidemics, significant population migration, natural resources depletion, climate changes, etc.

the resources that are needed (human, material and technical, financial, infrastructural, informational, etc.) to provide sustainment and development of the defence and security forces and the military-industrial complex;

the financial capability of the state to cover SDS's needs;

the capabilities of the SDS components for interoperable activities with correspondent structures of NATO and EU countries in joint operations, which is conditioned by the defined strategic course of the state.

The goal of the CSDSR is achieved by the performance of a range of typical tasks, namely:

analysis and forecasting of the security and operational environment in the current and future dimensions;

assessment of security and operational environment and definition of the tasks for the defence and security forces of Ukraine;

forecasting of scenarios and situations which are sufficiently robust to fully challenge the future Ukrainian Joint Force. The scenarios 
should include a variety of types of threats;

capability assessment of SDS's components to operate in the future scenarios as well as their joint capabilities;

defining the complex set of measures to achieve the necessary joint capability of SDS and its components, as well as to carry out reforms in the spheres of national security and defence;

forecasting the prospects of development, the modern models of the SDS and its components' that would provide the desired level of response to actual and potential threats in middle- and long-time perspective within the conditions of the effective usage of allocated resources;

creation of an informational-analytical base for the elaboration of realistic conceptions of SDS development, providing national security strategy implementation in corresponding spheres, relevant programs, and planning documents within the defined rules and restrictions.

As a basis for the organization and implementation of the CSDSR and the formation of planning documents in the spheres of national security and defence the methodology of a capability-based review has been adopted, which proved itself to be effective in NATO countries, and the experience of similar reviews that have been conducted in Ukraine (Dieniezhkin M. M., Krykun P. M., 2008).

The CSDSR algorithm harmonically combines the measures of individual reviews and assessment of joint SDS's capabilities. It is achieved by the system of working bodies, informational, material, technical, staff, legal and methodological support of the review process.

The CSDSR is held in three stages preparation (organizational), main (executive), and conclusive (final).

The preparation stage starts by the Decree of the President of Ukraine which brings into effect the decision of the National Security and Defence Council (NSDC) on the CSDSR.

Based on the results of the review at this stage, the operating bodies at the interagency and agency levels shall be formed, personnel shall be trained, the CSDSR measures planned, and the documents for management, organization, planning, methodology, information, and other subjects shall be approved.

The main stage is conducted basing on approved organizational, planning, and other CSDSR documents. It should combine processes of analytics, assessment, solution analysis, and propositions.

This stage includes such key procedures:

security and operational environment assessment, including forecasting of potential threats, and the description of scenarios and situations in which security and defence forces may be jointly used with the support of other SDS components;

review and assessment of the joint capability of SDS and its component as well as the development of the vision for their further development;

resource analysis and the vision of its management to provide for the effective use and development of capabilities of the SDS's components on a long-term perspective;

substantiation of indicative indexes of the state opportunities for providing resources for SDS's components performance and development.

The outputs of the researchers and assessment have been got at this stage make the basis of CSDSR results.

During the conclusive stage:

CSDSR results are generalized;

preliminary results are discussed;

lessons learned of the reviews are generalized;

CSDSR report materials are prepared for consideration at the meeting of NSDC of Ukraine.

A presentation of CSDSR results is prepared for civil society.

The CSDSR results are considered and approved by the National Security and Defence Council of Ukraine. Based on this decision and for its implementation, relevant program and planning documents are prepared. Herewith the so-called "cross planning" method is used: each of SDS's bodies performs capability development planning taking into consideration 
their joint performance with other SDS bodies, the fulfilment of its own objective or the passing of the capability to another state body while performing the tasks in the defined scenarios and situations in which security and defence forces may be applied. Such an approach gives an opportunity to unite the capability of the SDS's components, to focus the efforts on performance of national security priority tasks of Ukraine, state's security and defence institutions optimization, and to exclude the duplication of bodies, and as a result - sufficient savings of resources.

The CSDSR results, in general, are aimed: for the achievement of the strategic goal, substantiation of strategic tasks and ways of their achievement; performance of tasks of SDS and its components as the long-term perspective, which makes the basis for program and planning documents; distribution of strategic priorities according to the significance of individual tasks in correspondent strategies formation.

Such methodological and organizational approach for conducting of the CSDSR and the implementation of its results gives an opportunity to consider a structure of the strategies in the spheres of the national security and defence in respect of three aspects at once: (1) the vision of SDS and its components in the expected future security environment; (2) the elaboration of the vision for the strategic plans of SDS's components actions towards addressing potential risks and threats, as well as (3) the development of the necessary capability.

To conduct the CSDSR, a system of operating bodies is created. It provides coordination of the actions of the CSDSR' participants, as well as timely and proper performance of the planned measures. It includes the Interagency Working Group on the CSDSR, working groups, and consulting bodies. The Interagency Working Group is the main operating body for the organization and conduct of the review and it is created by NSDC decision and the Conclusions

The conducting of CSDSR in accordance with the above-mentioned logic and order gives correspondent Act of the President of Ukraine. Its effective activity is provided by the political will of the top authority of the state to strengthen the security and defensive potential of the country.

The CSDSR provides a wide range of consulting assistance, including national and foreign experts and consultants, and cooperation with them is organized in the following directions:

elaboration of review methodology;

analysis of joint capabilities of the SDS and the abilities of its components, as well as the definition of the directions of their development under European and Euro-Atlantic principles and approaches;

implementation of the capability-basis planning approach and modern resource management in SDS components under the single methodology;

national crisis management system assessment;

development of the coordinated militaryand-technical and military-industrial policy of the SDS and other directions of methodological assistance.

Informing the society on the course of the CSDSR and its intermediate results was organized on a constant basis. The web-sites of the Office of the President of Ukraine, NSDC, Cabinet of Ministers of Ukraine, and the correspondent ministries are used for this purpose.

Special attention is paid to the elaboration of appeals from citizen and public organizations concerning the CSDSR. Propositions and remarks set forth in those appeals are analyzed in order to consider them in the process of the reviews. Within the framework of SDS's partnership with society, different forms of voluntary citizens' participation in national security providing are studied. One of the bright lessons learned of such a relationship is a volunteer movement during the fighting against Russian armed aggression in the East of Ukraine.

Ukraine an opportunity to realize modern methods for the assessment of the security and 
defence sector, to implement capability-based planning for all SDS bodies by a single methodology, and to implement European and Euro-Atlantic principles and approaches regarding the development of the SDS and its components.

The CSDSR implementation as an integral component of planning in the spheres of the national security and defence favours systemic research of SDS operation and reasonable decisions on issues of national security of
Ukraine, as well as the development of realistic program and planning documents.

The implementation of the CSDSR results provides the development of SDS as a complete functional system ensuring national security and defence, and the achievement of the necessary joint capabilities and capacity of the SDS and its components. As such, the appropriate distribution of resources and their management favours their targeted and effective use.

\section{References}

Law of Ukraine on National Security of Ukraine, Available from: https://www.rada.gov.ua/ news/Novyny/161296.html.

Dieniezhkin M. M., Krykun P. M. (2008) Methodology of conduct of defence review. Science and Defence, \# 2, p. 20-29.

Telelym V., Muzychenko D., Punda Yu. (2014) Planning of forces to conduct combat tasks in "hybrid warfare". Science and Defence, \# 3, p. 30.

Dieniezhkin M. M. Krykun P. M., Rusnak I. S. (2014) Problems of conduct of complex overview of defense and security sector of Ukraine: considerations concerning its organization and task solving. Science and Defence, \# 4, p. 3-10. 